\title{
Sourcing and Management Practices by the Live-Goat Suppliers and Retailers in Lagos State, Nigeria
}

\author{
O. T. Sigbeku ${ }^{1}$, A. B. Omojola ${ }^{2} \&$ O. A. Ogunwole ${ }^{3}$ \\ ${ }^{1}$ Animal Feed and Premix Division, Veterinary Medicine and Allied Products Directorate NAFDAC, Isolo Lagos, \\ Nigeria \\ ${ }^{2}$ Animal Products and Processing Unit, Department of Animal Science, University of Ibadan, Ibadan, Nigeria \\ ${ }^{3}$ Agricultural Biochemistry and Nutrition Unit, Department of Animal Science, University of Ibadan, Ibadan, \\ Nigeria
}

Correspondence: O. A. Ogunwole, Agricultural Biochemistry and Nutrition Unit, Department of Animal Science, University of Ibadan, Ibadan, Nigeria. E-mail: oa.ogunwole@ui.edu.ng

Received: October 12, 2020

Accepted: January 4, $2021 \quad$ Online Published: January 15, 2021

doi:10.5539/jas.v13n2p101

URL: https://doi.org/10.5539/jas.v13n2p101

\begin{abstract}
The sourcing and management practices of the live-goat suppliers and retailers in Lagos State, Nigeria were evaluated. Sources of the live-goat and the husbandry practices on them by suppliers and retailers were determined, using three-stage sampling procedures. Three livestock markets each from Lagos East, West and Central Senatorial Districts were purposively selected. Nine suppliers and 18 retailers were randomly selected in each market resulting to 81 and 162 respondents, respectively. Data on sourcing, handling, and holding period of live-goat were collected using two well-structured questionnaires for the suppliers and retailers of goats. Results showed that most suppliers $(89.3 \%)$ purchased goats from open markets outside the state. The suppliers $(52.0 \%)$ and retailers $(80.0 \%)$ tethered goats. Most suppliers $(77.3 \%)$ and retailers $(90.0 \%)$ held goats for a maximum of three weeks, fed goats on dry grass sold in the open markets and some from open paddock. Routine administration of analgesic, dewormer, salt licks and water mainly sourced from boreholes and rivers were practices by both the suppliers and retailers. The age and level of education of the suppliers and retailers significantly influenced $(\mathrm{p}<$ 0.05 ) the management systems, handling, pest control, deworming, watering and additives used by the suppliers and retailers of goats. Most retailers $(90.0 \%)$ belonged to markets regulated by different sectorial market associations while the local and state government officials in the markets performed no regulatory roles. Therefore, live-goat in Lagos State were sourced from other parts of Nigeria, handled, and managed by the suppliers and then retailers prior to their disposal in a manner directly influenced by the age and levels of education of the practitioners.
\end{abstract}

Keywords: live-goat, Lagos State, holding period, sectorial markets associations, goats handling suppliers

\section{Introduction}

Lagos State is the most populous state in Nigeria with a current estimated human population of over 20 million being the most preferred destination of rural to urban migrants in Nigeria (LBS, 2013; Okuneye et al., 2016). It is the commercial capital of the country with history of existence dating back to 15th century. There is presently, no commercial farm that can meet the increasing demand for livestock products in the State with an ever-increasing population (Akinfolarin \& Okubanjo, 2010). Survey (Lawal-Adebowale, 2012; Aina, 2012) revealed that Nigeria had 13,900,000 cattle, 34,500,000 goats and 22,100,000 sheep while pigs and chicken were 3,000,000 and $85,000,000$, respectively. It was also reported that the stocks consumed in Lagos State were supplied from other parts of the country and outside the country (Akinfolarin \& Okubanjo, 2010). Recent insurgency in the North-East Nigeria and resultant displacement of most farmers in the region led to presumption that most animals supplied or retailed in Lagos State were from other parts of the country other than the North-East.

In view of the importance of meat in food, the demand and supply of meat in Nigeria cut across the rural and urban areas, meat and meat products are available in every Nigerian market irrespective of the location either rural or urban (Ologhobo, 2012). Poultry products (meat and eggs), goat meat (chevon) and beef serve as protein sources that are linked with little or no cultural and religious constraints. Other livestock products like pork and 
mutton are associated with cultural and religious believes which makes its consumption limited to some part of the country (Ojewola \& Onwuka, 2001). Adetunji and Rauf (2012) in their report classified mutton and pork as luxury foods while chicken, beef, and chevon were classified as normal food for the households.

Gambo et al. (2010) showed that Chevon is the second preferred meat type after beef amongst the working group and the most preferred by younger respondents (people less than or equal to 20 years old) in Maiduguri. Dipeolu (2010) also reported that the demand for meat and meat products is on the increase due to increased income of workers and rapid urbanization taking place across the country. The report also confirmed that chevon was considered a delicacy because of its peculiar taste and aroma. In the eastern part of the country, goat head consumption (Isiewu) and goat meat pepper soup are popular delicacy especially amidst youths and working class. The preference for goat meat amidst the Igbo tribe was reported to be extremely high (Obanu, 1975)

Most meat products are obtained from animals that were raised on a free-range management system (Olafadehan \& Adewumi, 2010). While raising these animals, they are exposed to environmental hazards and poor-quality inputs such as feed and water. The animals are generally poorly kept, and these could have a direct effect on their level of production and the quality of their products. Goats, for instance, are known to be browsers and scavengers (Aina, 2012). They enjoy moving around to fend for feed through grazing and browsing and obtain drink water from any available source irrespective of the quality and safety of such feed and water. Aina (2012) reported that goats are commonly raised in the rural areas by housewives, mostly for chevon. Meat and meat products especially chevon was reported to be readily available in both informal local markets and the formal markets (distributors/retailers shopping malls) in the rural and urban areas across Nigeria (Ologhobo, 2012).

The production, distribution, and sale of livestock in Nigeria is age-long business that dominate the northern and southern part of the country. Farmers and livestock merchants across the two parts of the country have a long-time trading relationship that have existed across generations (Akinsoye, 1986; Okoli et al., 2006). Livestock, especially large and small ruminants, are mainly raised under extensive system of management in the north due to favorable climate and absence of stock threatening diseases such as trypanosomiasis. Also, in the north are relative availability of crop residues which the animals can easily assess and feed on. This system of management is affordable for rural farmers. Lawal-Adebowale (2012) reported that the population of sheep and goat in Nigeria was 34.5 million with $70 \%$ of this population residing in the northern part of the country. He noted that the West African dwarf (WAD) breed of goat is predominately kept in the southern part of the country due to the adaptation of the breed and its socioeconomic value. Other breeds of goats especially, the Red Sokoto, are kept under intensive or semi-intensive care in the south when they are brought down for sale. The animals would either be kept in conferment or mostly tethered and fed concentrates and forages within a short period while awaiting buyers.

Scanty reports have been made on perception and consumption of different meat products mostly in Nigerian university campuses (Gambo et al., 2010; Akinwumi et al., 2011; Ogunwole \& Adedeji, 2014). However, there is paucity of information on the sources and the likely management practices of live-goats by the suppliers and retailers especially, in Lagos State. This study was therefore aimed at assessing the sources and the husbandry practices animals were subjected to by the live-goat suppliers and retailers in Lagos State, Nigeria.

\section{Materials and Methods}

\subsection{Study Area}

The study was carried out in Lagos State, Nigeria. The state is located approximately on longitude $3^{\circ} 24^{\prime}$ east of the Greenwich Meridian and latitude $6^{\circ} 27^{\prime}$ north of the equator. The State is the commercial capital of Nigeria with 20 local government areas and a land area approximately, $3,577 \mathrm{~km}^{2}$. The state has three Senatorial areas viz: Lagos East, West and Central, with over 20 million human population. The study covers the three Senatorial areas in the state.

\subsection{Sampling Procedure}

Two sets of structured questionnaires were administered on suppliers and retailers of goats in nine purposely selected livestock markets that are well known for the sale and distribution of live animals in the state. Three markets were selected in each of the three senatorial areas. A set of the questionnaire was administered to nine suppliers in each market while the second questionnaire was administered to eighteen retailers in each market resulting to 81 and 162 prospective respondents, respectively.

\subsection{Instrument of Data Collection}

The two questionnaires were well structured into two sections. The first section was on the demographic information of the respondents (suppliers and retailers) including their financial strength. The second section was 
designed to seek information on the actual management practices of the suppliers, or the retailers expected activities. The suppliers' questionnaire sought for the source of the animals, the type of animals being hawked, and the method used to raise the animals. The retailers' questionnaire was fashioned to gather information on the market, the general regulatory procedure in the market and the body responsible for the management of the market amidst other things. The questionnaires were developed based on information gathered from literature and similar work done on marketing of livestock in Nigeria (Jubril et al., 2012; Lawal-Adebowale, 2012). Copies of the questionnaire were administered to respondents and retrieved by hand. The questionnaires were preceded by a paragraph explaining the objective of the study. No personal information was included in the forms.

\subsection{Questionnaire Retrieval}

A total of 81 questionnaires was administered to suppliers and 162 to the retailers. At the end of the exercise, 75 questionnaires were retrieved form the suppliers (92.6\%) and 150 from the retailers $(92.6 \%)$.

\subsection{Statistical Analysis}

The result gathered was collated and summarized using descriptive statistics. The relationship between demographic characteristics and some selected attributes of both suppliers and retailers was analysed with Chi square tests.

\section{Results}

\subsection{Evaluation of the Practices of the Supplier of Live Goats to Lagos State Markets}

The demographic characteristics of the suppliers of live goats to markets in Lagos State, interviewed in the three senatorial areas of the state are presented in Table 1 . Most respondents $(50.7 \%)$ were youths while $25.3 \%$ were below ages 16-25. Precisely, $24.0 \%$ of the total respondents were aged above 40 years. Most respondents (80\%) were married while only $2.7 \%$ were illiterates and had no form of formal education. Most suppliers (49.3\%) interviewed had a minimum of secondary school education. Only $6.7 \%$ had more than 6 persons in their nuclear family and only $2.7 \%$ of the respondents had a monthly income less than N5,000.

Table 1. Demographic characteristics of suppliers of goats to markets in Lagos State

\begin{tabular}{|c|c|c|c|}
\hline Parameters & & Frequency & Percentage (\%) \\
\hline \multirow{4}{*}{ Age } & $16-25$ & 19 & 25.3 \\
\hline & $25-40$ & 38 & 50.7 \\
\hline & $>40$ & 18 & 24.0 \\
\hline & Total & 75 & 100 \\
\hline \multirow{4}{*}{ Marital status } & Single & 14 & 18.7 \\
\hline & Married & 60 & 80.0 \\
\hline & Widowed & 1 & 1.3 \\
\hline & Total & 75 & 100 \\
\hline \multirow{6}{*}{ Level of education } & Informal & 2 & 2.7 \\
\hline & Quran & 15 & 20.0 \\
\hline & Primary & 18 & 24.0 \\
\hline & Secondary & 37 & 49.3 \\
\hline & Tertiary & 3 & 4.0 \\
\hline & Total & 75 & 100 \\
\hline \multirow{4}{*}{ Family size } & $<6$ Persons & 40 & 53.7 \\
\hline & 6 Persons & 30 & 40.0 \\
\hline & $>6$ Persons & 5 & 6.7 \\
\hline & Total & 75 & 100 \\
\hline \multirow{6}{*}{ Income level/month } & $<\mathrm{N} 5,000$ & 2 & 2.7 \\
\hline & $<\mathrm{N} 10,000$ & 8 & 10.7 \\
\hline & $<\mathrm{N} 20,000$ & 33 & 44.0 \\
\hline & $<\mathrm{N} 40,000$ & 22 & 29.3 \\
\hline & $>\mathrm{N} 40,000$ & 10 & 13.3 \\
\hline & Total & 75 & 100 \\
\hline
\end{tabular}




\subsection{The Sourcing and Management of Goats Supplied to Markets in Lagos State}

The live-goat sourcing and the system of management before supplying to goat market in Lagos State is presented in Table 2 . Only $46.6 \%$ of the respondents sourced their stock from farmers and open market, while a substantial number of the suppliers (42.7\%) procured their stock solely from the open market. Most $(61.3 \%)$ of the respondents acknowledged free range system as the method of raising livestock. About $24.0 \%$ of the respondents confirmed they tethered their stocks. Intensive system was not a common management technique as none of the respondents acknowledged this. Only $14.7 \%$ indicated semi-intensive management system as the method of raising their stock. While $29.3 \%$ of the suppliers usually keep their stock for two weeks before delivering them to Lagos market, $10.7 \%$ do keep the animals for a month and $20 \%$ keep their stock less than a week. Most suppliers $(52.0 \%)$ held the animals by tethering though some still employed free range $(22.7 \%)$ and semi-intensive $(25.3 \%)$ systems of management.

Table 2. The sourcing and management of goats supplied to markets in Lagos State

\begin{tabular}{|c|c|c|c|}
\hline Parameters & & Frequency & Percentage $(\%)$ \\
\hline \multirow{4}{*}{ How animals are sourced } & Open market & 32 & 42.7 \\
\hline & Farmers & 8 & 10.7 \\
\hline & Both & 35 & 46.6 \\
\hline & Total & 75 & 100 \\
\hline \multirow{4}{*}{ Management system used in raising animal } & Free range & 46 & 61.3 \\
\hline & Tethering & 18 & 24.0 \\
\hline & Semi-intensive & 11 & 14.7 \\
\hline & Total & 75 & 100 \\
\hline \multirow{7}{*}{ How long animals are kept before delivering to Lagos } & $<1$ week & 15 & 20.0 \\
\hline & 1 week & 12 & 16.0 \\
\hline & 2 weeks & 22 & 29.3 \\
\hline & 3 weeks & 9 & 12.0 \\
\hline & 1 month & 9 & 12.0 \\
\hline & $>1$ month & 8 & 10.7 \\
\hline & Total & 75 & 100 \\
\hline \multirow{4}{*}{ Management system used in keeping animals before selling } & Free range & 17 & 22.7 \\
\hline & Tethering & 39 & 52.0 \\
\hline & Semi-intensive & 19 & 25.3 \\
\hline & Total & 75 & 100 \\
\hline
\end{tabular}

\subsection{The Management of Live-Goat by the Suppliers'}

The management system by the suppliers of live goat in Lagos State markets is presented in Table 3. Most suppliers $(77.3 \%$ ) dewormed their stock, $53.4 \%$ administered antibiotics while only $12.0 \%$ of the respondents gave Caffeinol (an analgesic pharmaceutical product). Most respondents $(72.0 \%)$ believed they needed to carry out the above measures as routine treatment for the animals though $82.7 \%$ acknowledged that the above measures would affect the quality of meat from the animals. Most suppliers (61.4\%) fed dry grass sold in the open market to their animals, although, $52.0 \%$ sourced feed from open paddock for their animals. While $50.7 \%$ of the respondents gave salt lick to their stock as feed supplement, $49.3 \%$ of them did not see the need for that. A close observation of the respondents revealed that animals kept by $38.6 \%$ of the respondents licks metal cage while $34.7 \%$ licks dry soil. Only $2.7 \%$ of the respondents did not notice any of such reactions on their animals. Most respondents (64.0\%) did not determine the age of their stock, only $36.0 \%$ determined the age of their stock, which were estimated at between 3 years $(37.3 \%)$ and above $(36.0 \%)$. 
Table 3. The management practices suppliers's stock are exposed to in Lagos State

\begin{tabular}{|c|c|c|c|}
\hline Parameters & & Frequency & Percentage $(\%)$ \\
\hline \multirow{4}{*}{ Management practices carryout while keeping the animals } & Deworm & 58 & 77.3 \\
\hline & Delouse & 12 & 16.0 \\
\hline & De-tick & 4 & 5.3 \\
\hline & Fatten & 1 & 1.4 \\
\hline \multirow{4}{*}{ Do you add any of the following to water? } & Antibiotics & 40 & 53.4 \\
\hline & Salt & 19 & 25.3 \\
\hline & Caffeinol & 9 & 12.0 \\
\hline & Wheat/maize offal & 7 & 9.3 \\
\hline \multirow{3}{*}{ Why add the items above? } & Treatment & 54 & 72.0 \\
\hline & Growth & 15 & 20.0 \\
\hline & Agility & 6 & 8.0 \\
\hline \multirow{3}{*}{$\begin{array}{l}\text { Do you think that addition of any of the } \\
\text { items above will affect the quality of the meat? }\end{array}$} & No & 8 & 10.7 \\
\hline & Yes & 62 & 82.7 \\
\hline & Indifferent & 5 & 6.6 \\
\hline \multirow{4}{*}{ Feed offer to animals } & Wet grass & 16 & 21.3 \\
\hline & Dry grass from open market & 46 & 61.4 \\
\hline & Concentrate & 10 & 13.3 \\
\hline & Others & 3 & 4.0 \\
\hline \multirow{4}{*}{ Source of feed } & Swampy area & 25 & 33.3 \\
\hline & Industrial area & 3 & 4.0 \\
\hline & Open paddock & 39 & 52.0 \\
\hline & Roadside & 8 & 10.7 \\
\hline \multirow{2}{*}{ Do you give animals salt lick? } & Yes & 38 & 50.7 \\
\hline & No & 37 & 49.3 \\
\hline \multirow{7}{*}{ Traits exhibited by animals } & Licking mud house wall & 2 & 2.7 \\
\hline & Licking of wall paint & 6 & 8.0 \\
\hline & Licking of metal cage & 29 & 38.6 \\
\hline & Licking of galvanized wire & 9 & 12.0 \\
\hline & Licking of dry soil & 26 & 34.7 \\
\hline & Biting of sticks & 1 & 1.3 \\
\hline & Do not notice such actions & 2 & 2.7 \\
\hline \multirow{2}{*}{$\begin{array}{l}\text { Do you determine the relative age } \\
\text { of animals before buying? }\end{array}$} & Yes & 27 & 36.0 \\
\hline & No & 48 & 64.0 \\
\hline
\end{tabular}

\subsection{Issues With Availability of Clean and Safe Water Supply}

The suppliers' source of water served to their stock is presented in Figure 1. Over 50.0\% of the respondents' fetched water for their stock from well/borehole, $20.0 \%$ from the river while other respondents sourced water from stream, drainage, and stored water from rainfall. The material used to serve water to the animals, which contributes to the safety of the water supply, was mostly improvised water trough using the half cut of metal drum to present water to stock. 


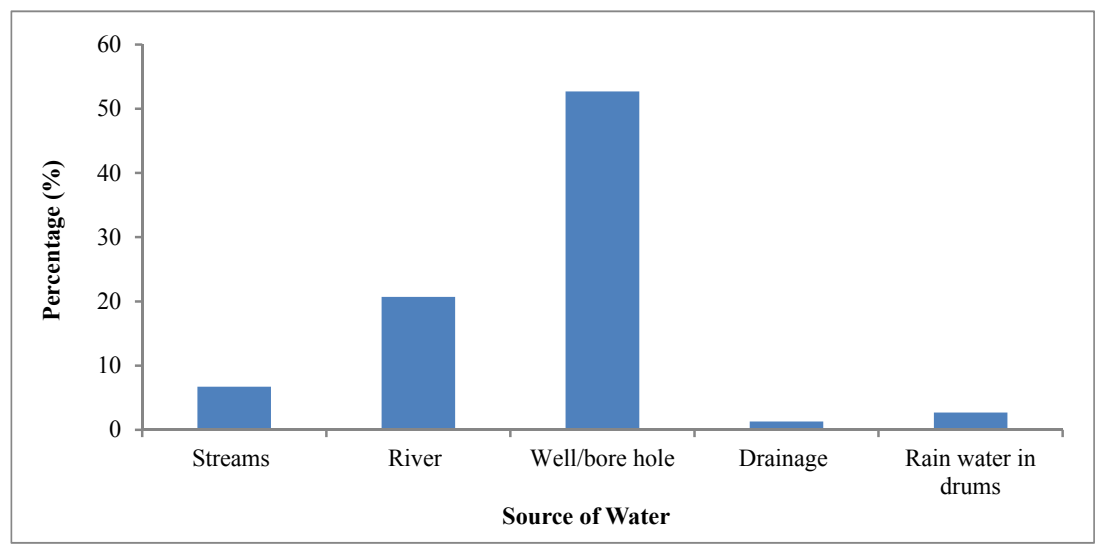

Figure 1. Suppliers' source of water for goats supplied to Lagos market

\subsection{Chi Square $\left(\chi^{2}\right)$ Test Showing the Relationship Between Personal Characteristics and Some Attributes of the Suppliers}

Some of the demographic characteristics (age, marital status, education, and income) of the suppliers were compared with some actions taken on the animals and the result is presented in Table 4. The age and level of education of the suppliers significantly influenced $(p<0.05)$ the management system employed in handling the stock, especially deworming. Education and level of income of the supplier had a significant influence $(p<0.05)$ on the source of water for the stock. None of the measured demographic attributes significantly influenced $(\mathrm{p}>$ 0.05 ) the type of animal supplied and any of the additive used for the stock.

Table 4. Relationship between personal characteristics and selected attributes of suppliers

\begin{tabular}{|c|c|c|c|c|c|c|c|c|c|}
\hline \multirow{2}{*}{ Attributes/Parameter } & & \multicolumn{2}{|c|}{ Age } & \multicolumn{2}{|c|}{ Marital Status } & \multicolumn{2}{|c|}{ Education } & \multicolumn{2}{|c|}{ Income } \\
\hline & & $\chi^{2}$ & $\mathbf{P}$ & $\chi^{2}$ & $\mathbf{P}$ & $\chi^{2}$ & $\mathbf{P}$ & $\chi^{2}$ & $\mathbf{P}$ \\
\hline \multirow{4}{*}{ Animal supplied } & Cattle & 2.58 & 0.28 & 3.15 & 2.07 & 0.87 & 0.93 & 7.53 & 0.11 \\
\hline & Ram & 0.99 & 0.61 & 0.51 & 0.78 & 3.88 & 0.42 & 5.97 & 0.20 \\
\hline & Sheep & 0.36 & 2.01 & 0.51 & 0.77 & 2.11 & 0.72 & 4.51 & 0.34 \\
\hline & Goat & 1.62 & 0.45 & 0.17 & 0.92 & 2.58 & 0.63 & 7.32 & 0.12 \\
\hline \multirow{3}{*}{ Management system by suppliers } & Deworm & $10.15 \%$ & 0.01 & 0.32 & 0.85 & $11.99 *$ & 0.02 & 2.44 & 0.66 \\
\hline & Delouse & 1.32 & 0.52 & 0.54 & 0.76 & 1.69 & 0.79 & 5.56 & 0.24 \\
\hline & De-tick & 2.26 & 0.52 & 1.06 & 0.59 & 5.62 & 0.23 & $9.88 *$ & 0.04 \\
\hline \multirow{5}{*}{ Source of water } & Stream & 1.33 & 0.51 & 3.03 & 0.22 & 2.90 & 0.58 & 2.95 & 0.57 \\
\hline & River & 0.66 & 0.72 & 0.11 & 0.95 & $9.55^{*}$ & 0.05 & $18.03 *$ & 0.00 \\
\hline & Well & 3.14 & 0.21 & 2.83 & 0.24 & 5.35 & 0.27 & 2.62 & 0.62 \\
\hline & Drainage & 0.38 & 0.82 & 0.47 & 0.79 & 3.37 & 0.50 & 2.64 & 0.62 \\
\hline & Rainwater & 1.10 & 0.58 & 0.51 & 0.77 & $18.25^{*}$ & 0.01 & 0.86 & 0.93 \\
\hline \multirow{4}{*}{ Addition of the followed by } & Antibiotics & 0.72 & 0.70 & 0.94 & 0.63 & 5.30 & 0.26 & 4.00 & 0.41 \\
\hline & Salt & 7.61 & 0.12 & 7.12 & 0.13 & 9.04 & 0.34 & 5.22 & 0.73 \\
\hline & Caffeinol & 8.51 & 0.74 & 6.71 & 0.15 & 7.05 & 0.53 & 5.67 & 0.69 \\
\hline & Wheat/corn offal & 3.40 & 0.49 & 4.59 & 0.33 & 8.00 & 0.43 & 0.81 & 0.95 \\
\hline
\end{tabular}

Note. ${ }^{*}$ Chi Square Value Significant at 5\% (0.05).

\subsection{Practices of the Retailers of Live Goat at Lagos State Markets}

The demographic characteristics of the respondents which engaged in the retail of live goats in Lagos State are presented in Tables 5 . Out of 150 respondents, only $40.7 \%$ of the respondents were within the age of 16-25 years, $39.3 \%$ were within the working age group of $25-40$ years and $18.7 \%$ and over 41 years old. Most of the respondents $(58.0 \%)$ were married, $36.0 \%$ were single and only $6.0 \%$ were widow. Most of the respondents (79.4\%) had up to secondary school education. The retailers in Lagos markets keep a relatively small family size only $17.3 \%$ had more than 6 persons in their nuclear family. Only $4 \%$ of the respondents had a monthly income less than $\mathrm{N} 5,000$. 
Table 5. Demographic characteristics of retailers of goats in Lagos State markets

\begin{tabular}{|c|c|c|c|}
\hline Parameter & & Frequency & Percentage (\%) \\
\hline \multirow{5}{*}{ Age } & $<16$ & 2 & 1.3 \\
\hline & $16-25$ & 61 & 40.7 \\
\hline & $25-40$ & 59 & 39.3 \\
\hline & $>41$ & 28 & 18.7 \\
\hline & Total & 150 & 100 \\
\hline \multirow{4}{*}{ Marital status } & Single & 54 & 36.0 \\
\hline & Married & 87 & 58.0 \\
\hline & Widowed & 9 & 6.0 \\
\hline & Total & 150 & 100 \\
\hline \multirow{6}{*}{ Level of education } & Informal & 5 & 3.3 \\
\hline & Quran & 3 & 2.0 \\
\hline & Primary & 14 & 9.3 \\
\hline & Secondary & 119 & 79.4 \\
\hline & Tertiary & 9 & 6.0 \\
\hline & Total & 150 & 100 \\
\hline \multirow{4}{*}{ Family size } & $<6$ Persons & 53 & 35.4 \\
\hline & 6 Persons & 71 & 47.3 \\
\hline & $>6$ Persons & 26 & 17.3 \\
\hline & Total & 150 & 100 \\
\hline \multirow{6}{*}{ Income level/month } & $<\mathrm{N} 5,000$ & 6 & 4.0 \\
\hline & $<\mathrm{N} 10,000$ & 42 & 28.0 \\
\hline & $<\mathrm{N} 20,000$ & 56 & 37.3 \\
\hline & $<\mathrm{N} 40,000$ & 37 & 24.7 \\
\hline & $>\mathrm{N} 40,000$ & 9 & 6.0 \\
\hline & Total & 150 & 100 \\
\hline
\end{tabular}

\subsection{The Dynamics of Live-Goat Retailers Market in Lagos State}

Some parameters of the goat markets sampled in Lagos State are presented in Table 6. Most respondents (43.3\%) were found in markets which has been in existence between 26 and 30 years. Most markets $(85.3 \%)$ in the state engaged in the sale of more than one species of livestock, only $14.7 \%$ of the markets was dedicated to the sale of live goats alone. Majority of the retailers $(74.7 \%)$ did not determine the age of the animals before stocking while $40.7 \%$ do stock the animals on average of three weeks before selling.

The pictorial representation of the organisations which regulates the activities in the markets is shown in Figure 2. About $90 \%$ of the markets visited were regulated by different sectorial market associations. Although the local and state government officials were found in the market but had little or no regulatory roles. 
Table 6. Some parameters of goat markets sampled in Lagos State

\begin{tabular}{|c|c|c|c|}
\hline Parameter & & Frequency & Percentage $(\%)$ \\
\hline \multirow{6}{*}{$\begin{array}{l}\text { Length of time the market has } \\
\text { been operational (years) }\end{array}$} & $<15$ & 42 & 28.0 \\
\hline & $16-20$ & 10 & 6.7 \\
\hline & $21-25$ & 32 & 21.3 \\
\hline & $26-30$ & 65 & 43.3 \\
\hline & $>30$ & 1 & 0.7 \\
\hline & Total & 150 & 100 \\
\hline \multirow{3}{*}{ Type of livestock sold at the market } & One (only goat) & 22 & 14.7 \\
\hline & More than One & 128 & 85.3 \\
\hline & Total & 150 & 100 \\
\hline \multirow{3}{*}{$\begin{array}{l}\text { Do you determine the relative } \\
\text { age of animals before stocking? }\end{array}$} & Yes & 38 & 25.3 \\
\hline & No & 112 & 74.7 \\
\hline & Total & 150 & 100 \\
\hline \multirow{7}{*}{$\begin{array}{l}\text { How long on the average do you keep } \\
\text { the animals before selling (week)? }\end{array}$} & $<1$ & 9 & 6.0 \\
\hline & 1 & 10 & 6.7 \\
\hline & 2 & 55 & 36.6 \\
\hline & 3 & 61 & 40.7 \\
\hline & 4 & 6 & 4.0 \\
\hline & $>4$ & 9 & 6.0 \\
\hline & Total & 150 & 100 \\
\hline
\end{tabular}

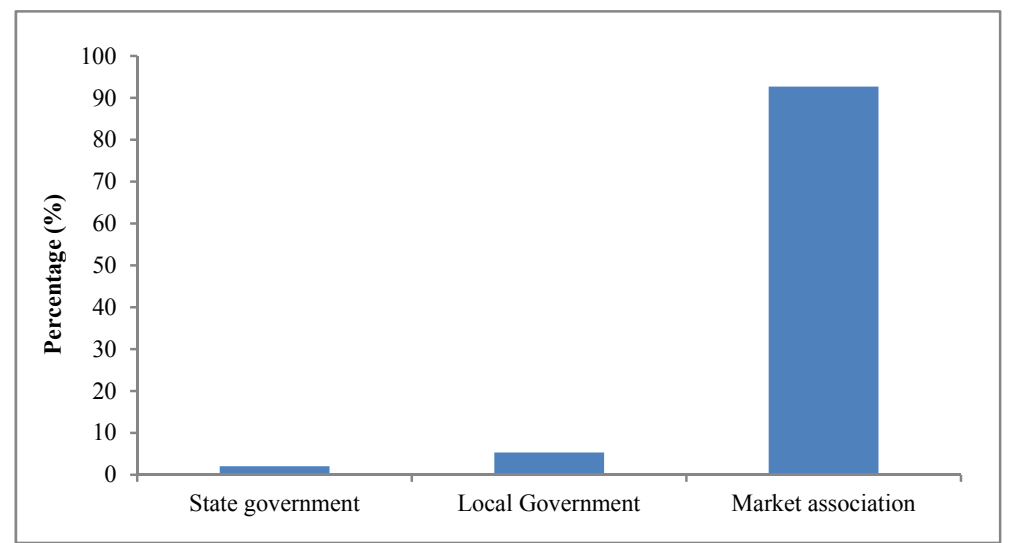

Figure 2. Organisations that regulate and control the goat retail market in Lagos State

\subsection{The Management Practices Retailers Used to Handle Their Stock}

The management system by the retailers of live goats in Lagos State markets while awaiting buyers is presented in Tables $7 \mathrm{a}$ and $7 \mathrm{~b}$. Most respondents $(80.0 \%$ ) held the animals by tethering while $13.3 \%$ still engaged in free range system of management. Only $28.7 \%$ of the respondents dewormed their stock, $44.0 \%$ delouse the stock. Some of the respondents (39.3\%) administered antibiotics to the animals while $10.7 \%$ gave caffeinol (an analgesic pharmaceutical product). Most retailers (52.0\%) believed they needed to carry out the measures as a basic treatment for the animals, $62.0 \%$ acknowledged that the above measures will affect the quality of the meat from the animals. While $56.0 \%$ of the respondents fed dry grass sold in the open market to the animals, only $38 \%$ gave salt lick to their stock as feed supplement. 
Table 7a. The management practices retailers' stock are exposed to in Lagos State

\begin{tabular}{llll}
\hline Parameter & & Frequency & Percentage (\%) \\
\hline & Free range & 20 & 13.3 \\
& Tethering & 120 & 80.0 \\
Management system used in keeping animals & Semi-intensive & 9 & 6.0 \\
& Intensive & 1 & 0.7 \\
& Total & $\mathbf{1 5 0}$ & $\mathbf{1 0 0}$ \\
Routine practices & Deworming & 43 & 28.7 \\
& Delousing & 66 & 44.0 \\
& De-ticking & 39 & 26.0 \\
& Fattening & 2 & 1.3 \\
& Total & $\mathbf{1 5 0}$ & $\mathbf{1 0 0}$ \\
Do you add the following to water? & Antibiotic & 59 & 39.3 \\
& Salt & 74 & 49.3 \\
& Caffeinol & 16 & 10.7 \\
& Wheat/maize offal & 1 & 0.7 \\
& Total & $\mathbf{1 5 0}$ & $\mathbf{1 0 0}$ \\
& Treatment & 78 & 52.0 \\
Why add the items above? & Growth & 9 & 6.0 \\
& Agility & 42 & 28.0 \\
& No reason (culture) & 21 & 14.0 \\
& Total & $\mathbf{1 5 0}$ & $\mathbf{1 0 0}$ \\
\hline
\end{tabular}

Table 7b. The management practices retailers' stock are exposed to in Lagos State

\begin{tabular}{llll}
\hline Parameter & & Frequency & Percentage (\%) \\
\hline Do you think that addition of any of the items & Yes & 43 & 28.7 \\
above will affect the quality of the meat? & No & 93 & 62.0 \\
& Indifferent & 14 & 9.3 \\
& Total & $\mathbf{1 5 0}$ & $\mathbf{1 0 0}$ \\
\hline Feeds animals are exposed to & Wet grass & 42 & 28.0 \\
& Dried grass & 84 & 56.0 \\
& Concentrates & 1 & 0.7 \\
& Combination of all & 23 & 15.3 \\
& Total & $\mathbf{1 5 0}$ & $\mathbf{1 0 0}$ \\
\hline Do you give salt lick to your animals? & Yes & 57 & 38.0 \\
& No & 93 & 62.0 \\
& Total & $\mathbf{1 5 0}$ & $\mathbf{1 0 0}$ \\
\hline
\end{tabular}

\subsection{The Source of Water and Watering of Retailers'Stock in Lagos Market}

The source of water used in watering the stock in the market while awaiting buyers is shown in Figure 3. Most retailers $(54.0 \%)$ sourced water from well or bore hole (depending on the depth of the water table), $20 \%$ sourced from the river while other respondents sourced from stream and drainage. The materials used as water trough by retailers in Lagos market were mostly stainless-steel basin and metal drum. Only $58.0 \%$ of the respondents used stainless steel basin as water trough, others used metal trough (38.5\%) (half cut of a metal drum) and cement pots $(3.5 \%)$. 


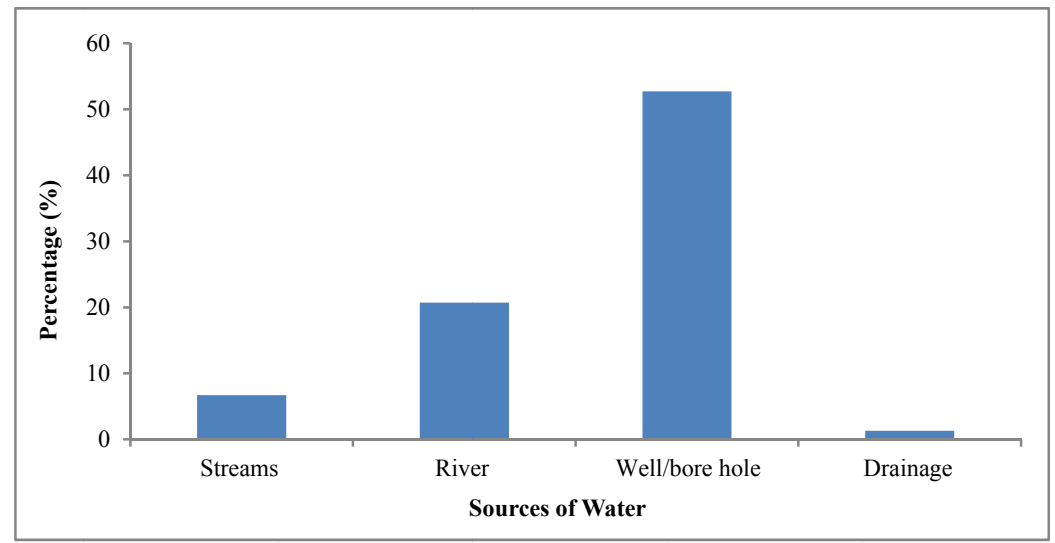

Figure 3. Retailers' sources of water for goats in Lagos Market

\subsection{Sourcing of Live Goats sold in Lagos Market}

Figure 4 shows the pictorial expression of species of ruminants supplied to the retail markets. Precisely $70.0 \%$ of animals supplied to the market was goat. Other species supplied were cattle (12.0\%) and sheep (18.0\%).

The sources of goats supplied to Lagos market are shown in Figure 5. Most (53.3\%) of the live goats supplied to Lagos State market were from the North West of Nigeria, while $17.3 \%$ were from south west, $10.7 \%$ from the north east and $10.0 \%$ of the retailers did not have the idea of where others were sourced from.

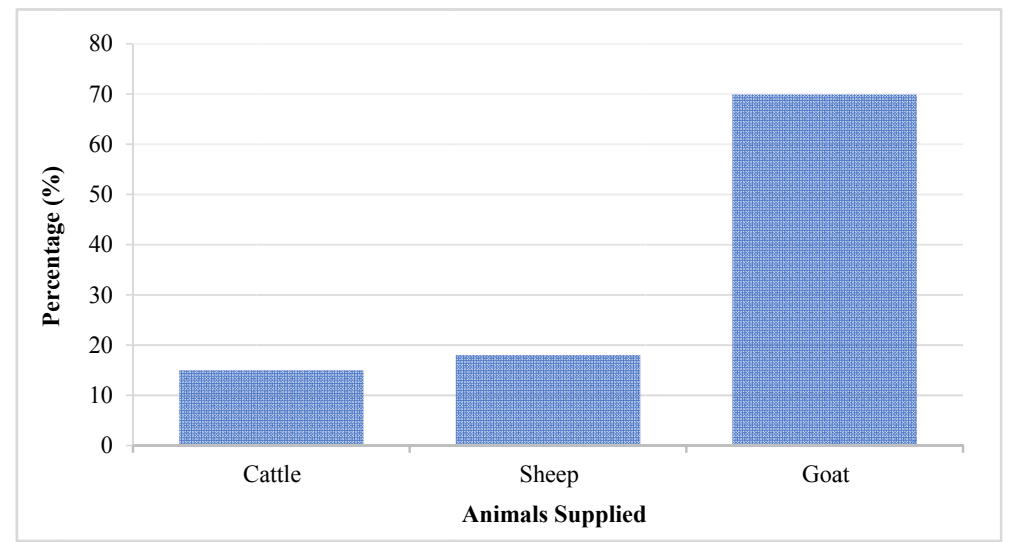

Figure 4. Percentage of animals supplied to live animal retail markets in Lagos State

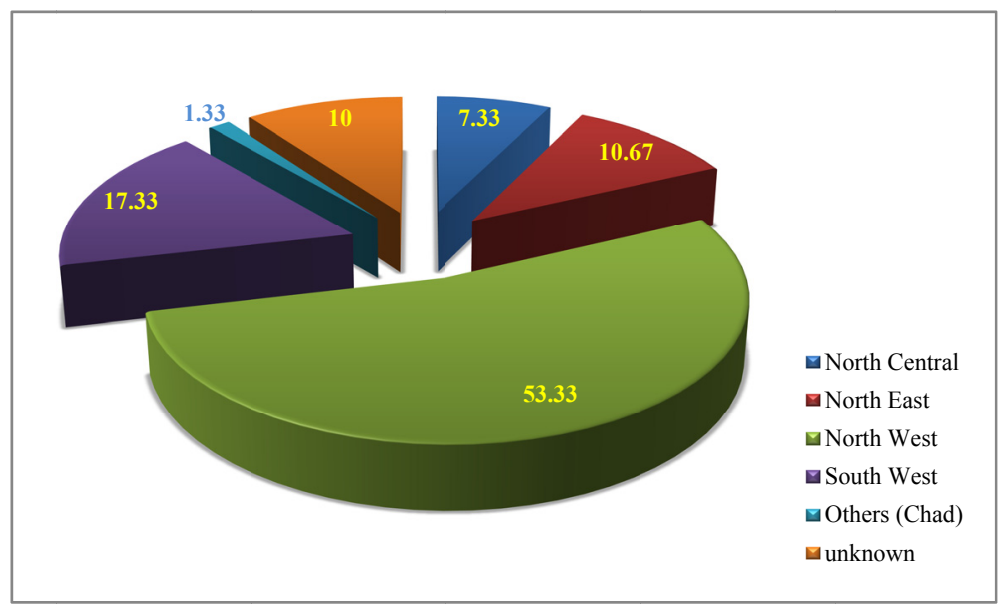

Figure 5. Sources of goats supplied for retail in Lagos markets 


\subsection{Chi Square $\left(\chi^{2}\right)$ Test Showing the Relationship Between Personal Characteristics and Some Selected Attributes of the Retailers}

The demographic characteristics of the live goat retailers were compared with some actions taken on the animals using chi square analysis. The results on Table 8 , shows the species of animals handled by the retailers were influenced $(p<0.05)$ by the retailers' age, marital status, level of education and level of income while the age and level of education of retailers had significant influence $(\mathrm{p}<0.05)$ on the stock management system. Other parameters were influenced $(\mathrm{p}<0.05)$ by age, marital status, and level of education of the retailers were delousing and sourcing of water from river. The retailers age, levels of education and income significantly influenced $(p<0.05)$ the determination of animals age before stocking. However, level of income of the retailers significantly influenced $(\mathrm{p}<0.05)$ the type of material used as water trough and addition of additives such as antibiotics, salt and caffeinol to the animal feed and water.

Table 8. Relationship between personal characteristics and some selected attributes of respondents

\begin{tabular}{|c|c|c|c|c|c|c|c|c|}
\hline \multirow{2}{*}{ Attributes/Parameter } & \multicolumn{2}{|c|}{ Age } & \multicolumn{2}{|c|}{ Marital Status } & \multicolumn{2}{|c|}{ Education } & \multicolumn{2}{|c|}{ Income } \\
\hline & $\chi^{2}$ & $\mathbf{P}$ & $\chi^{2}$ & $\mathbf{P}$ & $\chi^{2}$ & $\mathbf{P}$ & $\chi^{2}$ & $\mathbf{P}$ \\
\hline Cattle & $15.38^{*}$ & 0.00 & 1.39 & 0.50 & $18.21 *$ & 0.00 & $53.91 *$ & 0.00 \\
\hline Animal Available: Ram & 0.68 & 0.88 & 0.18 & 0.92 & 4.97 & 0.29 & 5.81 & 0.21 \\
\hline Sheep & 2.04 & 0.57 & $8.25^{*}$ & 0.02 & 6.26 & 0.18 & 2.14 & 0.71 \\
\hline Goat & 1.72 & 0.63 & 1.13 & 0.57 & $11.74 *$ & 0.02 & 7.38 & 0.12 \\
\hline Mgt. system use in stocking & $17.94 *$ & 0.04 & 3.85 & 0.70 & $53.89 *$ & 0.00 & 12.71 & 0.40 \\
\hline Deworm & 4.76 & 0.19 & 6.60 & 0.04 & 7.30 & 0.12 & $26.23^{*}$ & 0.00 \\
\hline Mgt. system Delouse & $12.27 *$ & 0.00 & $11.27^{*}$ & 0.00 & $11.20 *$ & 0.02 & $28.00^{*}$ & 0.00 \\
\hline by retailers De-tick & $13.29 *$ & 0.00 & 4.75 & 0.09 & 7.92 & 0.10 & $18.79 *$ & 0.00 \\
\hline Fattening & 0.51 & 0.92 & 1.47 & 0.48 & 0.53 & 0.97 & 1.39 & 0.85 \\
\hline Stream & 0.76 & 0.86 & 2.30 & 0.32 & 1.37 & 0.85 & 3.88 & 0.42 \\
\hline Source of water River & $9.40^{*}$ & 0.02 & $12.40 *$ & 0.00 & $17.71 *$ & 0.00 & 2.80 & 0.59 \\
\hline Well/borehole & 4.62 & 0.20 & 1.53 & 0.47 & 7.69 & 0.10 & $26.72 *$ & 0.00 \\
\hline Drainage & 2.96 & 0.40 & 3.60 & 0.17 & 0.53 & 0.97 & 1.14 & 0.88 \\
\hline Half metal drum & 5.96 & 0.11 & 4.20 & 0.12 & 7.19 & 0.13 & $30.86^{*}$ & 0.00 \\
\hline Type of water stainless steel & 5.77 & 0.12 & 2.65 & 0.27 & 2.50 & 0.65 & $30.74 *$ & 0.00 \\
\hline trough cement pot & 1.01 & 0.79 & 1.43 & 0.49 & 5.60 & 0.23 & 1.69 & 0.79 \\
\hline Antibiotics & 1.32 & 0.72 & 1.30 & 0.52 & 8.01 & 0.09 & $28.98^{*}$ & 0.00 \\
\hline Addition of the foll. Salt & 5.56 & 0.14 & 1.47 & 0.48 & 6.50 & 0.17 & $19.60 *$ & 0.00 \\
\hline Caffeinol & 1.02 & 0.80 & 3.78 & 0.15 & 2.43 & 0.66 & $15.62 *$ & 0.00 \\
\hline Wheat/corn offal & 1.47 & 0.69 & 1.79 & 0.41 & 0.63 & 0.99 & 2.59 & 0.63 \\
\hline Determine the relative age of Animal & $9.47 *$ & 0.02 & 0.64 & 0.73 & $11.28^{*}$ & 0.02 & $16.00^{*}$ & 0.00 \\
\hline
\end{tabular}

\section{Discussion}

\subsection{Ethical Practices of the Suppliers and Retailers of Live Goat in Lagos State Markets}

The demographic assessment of live goats' suppliers to Lagos market shows that $50.7 \%$ of the suppliers were youths (aged between 25 and 40 years) which agrees with the report of Jubril et al. (2012). In their report over $80 \%$ of traders involved in the transboundary trade of live animal in Katsina state were youths of the same age bracket. This, however, shows that, though livestock production might be in the hands of old illiterate herders in Nigeria (Lawal-Adebowale, 2012), the merchandizing of livestock is handled largely by the male youths that have at least secondary school level of education. Also, the suppliers were mostly married $(80 \%)$ and literate at various levels of education while the illiterates were just $2.7 \%$. This also agreed with Jubril et al. (2012) report where over $80 \%$ of respondents were married, $53 \%$ of the suppliers had a family size less than six persons. This could be because of education and civilization of the traders. Most of the traders were above poverty level as stipulated by World Bank (2015). Only 2.7\% earned less than N5,000 (\$13.7) in a month (at N365/USD) which could be below $\$ 1.90 /$ day international poverty line set by World Bank in 2015 . This could be because of common problems militating against livestock industry in Nigeria such as poor facility, lack of credit facility amongst other as reported (Lawal-Adebowale, 2012). 
The trend of the suppliers' demography was similar those of the retailers. Majority (80\%) were youth aged between 16 and 40 years. This also agrees with Jubril et al. (2012) report on Katsina state inter-boundary trade between Nigeria and Niger republic. The report showed that $80 \%$ of the traders were youth similar to the suppliers above, $58 \%$ of the retailers were married and only $3.3 \%$ were illiterate who do not have any form of education. Only $82.7 \%$ had a family size of six or less. These could be because of social impact of Lagos State being a mega city (urbanization), level of education was reported to be high in the state and few family members was common amidst the elite and educated (NBS, 2010; LBS, 2013).

\subsection{Dynamics of Goat Market in Lagos State}

The supplier of live goat to Lagos markets are generally traders that are into commerce. Their interest is on availability of stocks from economic viable and profitable sources. This probably accounted for the reason why the traders source their stock from both farmers and open markets. More suppliers acquired stock from open market (42.7\%) compared with those that procured from the farmers (10.7\%). Most of the suppliers (46.6\%) sourced their stock from both farmers and the open market. Generally, farmers are usually not willing to sell their stock indiscriminately. The number of animals in the possession of a farmer at a point in time is commonly used to measure wealth. The farmers use live goats to conserve their wealth and would only sell when they needed cash for very important purpose. The animal serves as bank for them (Aina, 2012).

Though, most suppliers could not emphatically state the management system used in raising the animals, but $61.3 \%$ strongly believed that the animals were raised on free range system. Most reports indicated that livestock production in Nigeria were mostly on free range system (Lawal-Adebowale, 2012; Aina, 2012; Ologhobo, 2012) and the animals were readily available for commercial purpose. Other management system observed was tethering $(24.0 \%)$ which was common in the marketplaces and at homestead where women, mostly use the system to restrain their stock for security purpose.

The length of time the suppliers keep the animals depends on the volume of demand by the retailers. The suppliers brought stocks to Lagos in anticipation that demand in the city were higher. However, other factors like weather, religious activities (fasting) and seasons do affect demand (Blench, 1999). In this study, 65.3\% of the respondent held animals within one day to two weeks which implied that most suppliers carried out their live goat supplying from the north to the south within an average of two weeks. The returns on investment as reported by Lawal-Adebowale (2012) were expected to be attractive. However, this study affirmed that no stock would be beyond three weeks especially when demand was low.

\subsection{The Management Practices of the Stocks Suppliers' and Retailers' in Lagos State}

It was observed that suppliers and retailers of live goats in Lagos State usually subject the animals to different treatments ranging from administration of additives (such as mineral salt lick) and drug (such as anti-stress and antibiotics) to different holding systems such as tethering. These management practices are expected to have impact on the animals; $77.3 \%$ of the suppliers and $28.7 \%$ of retailers deworm the animals while $16.0 \%$ of suppliers and $44.0 \%$ of retailers deloused the animals. These were done based on believe and adopted standard practise by the suppliers and retailers. Though, there are expert recommendations on the management of small ruminants (ILCA, 1979; Umunna et al., 2014), Most reports (ICS-Nigeria, n.d.; Aina, 2012) recommended a minimum of five to seven days and maximum 30 days for acclimatization period for new stock of animals. Goats are known to be rugged with endurance to hash conditions (Aina, 2012). Most traders, in the interest of their investment administered different drugs and additives to their stocks either out of fear of losing the animals to unknown and undiagnosed diseases or in the interest of making profit. This was reflected in the administration of caffeinol (a human analgesic) to animals by $12.0 \%$ suppliers to make the animal active and very agile, while $53.4 \%$ and $39.3 \%$ of the suppliers and retailers, respectively administered antibiotics without prescription to the animals. However, $25.3 \%$ and $49.3 \%$ of the suppliers and retailers provided the animals with mineral salt lick.

Findings revealed that these practices were carried out to keep the animals active and look healthy even when they may not be so. Most respondents (72.0\% suppliers and $52.0 \%$ retailers) believed these must be done as a treatment measures for the animals with or without consulting Veterinarian. Majority $(82.7 \%)$ of the suppliers agreed that these acts could affect meat quality and safety, $62.0 \%$ did not accept that the acts would affect the meat quality and safety. This practise was fraudulent because it was an act intentionally carried out solely for trade purpose. The possible health implication to human is the consumption of unwholesome meat ladened with drug residue and other unidentified contaminants which could be injurious to human health through damage to vital organs such as the kidney (Okocha et al., 2018). 


\subsection{Relationship Between Personal Characteristics of Selected Attributes of Suppliers and Retailers}

The age and level of education of the suppliers and the retailers had a significant influence $(p<0.05)$ on the management system of the stocks while education and level of income of the suppliers had significant influence $(p<0.05)$ on the source of water for the stock. The retailers' level of income had significant influence $(p<0.05)$ on the type of animals they trade, while age, marital status and level of education of the retailers was significant $(p<0.05)$ on the source of water for the stock. The retailers age, level of education and level of income had significant influence $(\mathrm{p}<0.05)$ on the determination of age of animals before stocking, however, level of income of the retailers had significant influence $(\mathrm{p}<0.05)$ on the type of material used as water trough and addition of additives such as antibiotics, salt and caffeinol to the animal feed and water. A review of the above practices shows that each activity along the value chain particularly, the distribution of goats in the markets depended on the level of education and capital available to the major players in each of the roles. Age and other factors though were significant but may not necessarily be the primary factors. This conformed to earlier reports (Lawal-Adebowale, 2012; Jubril et al., 2012) that participation in livestock trade depended mainly on capital available to the trader.

\section{Conclusion}

It was concluded in this study that most goats in Lagos State were sourced from other parts of Nigeria and supplied into the markets. The live-goat were subjected to various handling and management practices prior to disposal. The management systems were largely influenced by age, marital status, education, income level of the suppliers and retailers.

\section{References}

Adetunji, M. O., \& Rauf, M. O. (2012). Analysis of Household Demand for Meat in South-West Nigeria. Global Journal of Science Frontier Research Agriculture and Biology, 12(1), 15-21.

Aina, A. B. J. (2012). Goat (Capra hircus): A Misunderstood Animal (Inaugural Lecture Series 35). Federal University of Agriculture, Abeokuta.

Akinfolarin, B. O., \& Okubanjo, A. O. (2010). Human Population Growth Rate and Meat Supply in Lagos State (1991-2000). Acta SATECH, 3(2), 19-24.

Akinsoye, V. O. (1986). Senior Tropical Agricultural Science (p. 315). Macmillan Publishers, London.

Akinwumi, A. O., Odunsi, A. A., Omojola, A. B., Aworemi, J. R., \& Aderinola, O. A. (2010). Consumer Perception and Preference for Meat Types in Ogbomoso Area of Oyo State, Nigeria. International Journal of Applied Agricultural and Apicultural Research, 7(1\&2), 96-106.

Dipeolu, M. A. (2010). Healthy Meat for Wealth (Inaugural Lecture Series 29). Federal University of Agriculture, Abeokuta.

Gambo, B. G., Rauf, I. A., \& Ambali, A. G. (2010). Residents in Borno State and their meat Preference Among Ruminant Species. African Journal of General Agriculture, 6(2), 53-58.

ICS-Nigeria (Information and Communication Support for Agricultural Growth in Nigeria). (n.d.). Goat and Sheep Fattening Technique in Nigeria: A Commercial Livestock Production Guide Series.

ILCA. (1979). Small ruminant production in the humid tropics (Systems Study No. 3). ILCA, Addis Ababa, Ethiopia.

Jubril, S. A., Umar, S. M., \& Abdullahi, S. (2012). Economics of Cattle Marketing in Mai'adua International Border Market of Kastina State. Nigeria J. of Sci, Tech, and Education, 1(1), 76-81.

Lawal-Adebowale, O. A. (2012). Dynamics of Ruminant Livestock Management in the Context of the Nigerian Agricultural System. In K. Javed (Ed.), Livestock Production. In Tech. https://doi.org/10.5772/52923

LBS (Lagos Bureau of Statistics). (2013). Lagos State Literacy Survey. Ministry of Economic Planning and Budget.

NBS (National Bureau of Statistics). (2010). The National Literacy Survey. Retrieved December 20, 2020, from http://www.nigerianstat.gov.ng

Ogunwole, O. A., \& Adedeji, B. S. (2014). Consumers' Preference and Perception of the different types of Meat Among Staff and Students of the University of Ibadan, Nigeria. Journal of Agriculture and Environmental Sciences, 3(2), 77-95. 
Ojewola, G. S., \& Onwuka, G. I. (2001). Evaluation of the Organoleptic Properties of 'Suya' Produced from Various Sources of Meat. Nig. J Anim Prod, 28(2), 199-201.

Okocha, R. C., Olatoye, I. O., \& Adedeji, O. B. (2018). Food safety impacts of antimicrobial use and their residues in aquaculture. Public Health Rev, 39, 21. https://doi.org/10.1186/s40985-018-0099-2

Okoli, C. G., Okoli, I. C., Okorondu, U. V., \& Opara, M. N. (2006). Environmental and Public Health issues of Animal Food Products Delivery System in Imo State, Nigeria. Online Journal of Health and Allied Sciences, $5(2)$.

Okuneye, P. A., Adebayo, K., Opeolu, B. T., \& Baddru, F. I. (2016). Analysis of the Interplay of Migration and Urban Expansion, on Health and the Environment: The Case of Lagos, Nigeria (Thesis, Committee for International Cooperation in National Research in Demography).

Olafadehan, O. A., \& Adewumi, M. K. (2010). Livestock Management and Production System of Agropastorialist in the Derived Savanna of South West Nigeria. Tropical and Subtropical Agroecosystems, 12, 685-691.

Ologhobo, A. D. (2012). Feed Bio-Hazards: Life Destroyers and Life Enhancers (Inaugural Lecture). University of Ibadan, Nigeria.

Umunna, M. O., Olafadehan, O. A., \& Arowona, A. (2014). Small Ruminant Production and Management System in Urban Area of Southern Guinea Savanna of Nigeria. Asian Journal of Agriculture and Food Science, 2(2).

\section{Copyrights}

Copyright for this article is retained by the author(s), with first publication rights granted to the journal.

This is an open-access article distributed under the terms and conditions of the Creative Commons Attribution license (http://creativecommons.org/licenses/by/4.0/). 